If the roasted bird is not to be eaten until later it must be stored in a properly managed refrigerator, preferably at $4^{\circ} \mathrm{C}$ or below. The importance of this requirement is brought out in the report of a well-designed and conducted study by Toule and Murphy. ${ }^{1}$ They identified the bacteria contaminating refrigerated cooked chicken and examined their spoilage potential and possible origin. Briefly, they found that the variable temperature range common in a normal kitchen refrigerator $\left(2-13^{\circ} \mathrm{C}\right)$ resulted in a greater number of bacterial species and in total counts tenfold greater on the cooked chickens thus stored than in those kept at $4^{\circ} \mathrm{C}$ or below. The lesson is that refrigerators should be kept away from the humid atmosphere of cooking ovens, preferably in a different room, and that doors should be opened as seldom as possible and closed as quickly as possible. They found that cooked chicken was much more vulnerable to bacterial spoilage than was raw chicken and that a normal kitchen provided numerous sources of spoilage bacteria-including, for example, air of the kitchen and refrigerator, working surfaces, cutting equipment, socially clean plates, and water taps. Since many of these spoilage bacteria grow well and rapidly at refrigerator temperatures, they conclude that the shelf-life of cooked chicken is often no more than two days at $4^{\circ} \mathrm{C}$.

Hence, the precautions needed to keep our Christmas fare both safe and wholesome mean a reasonable amount of thought and care but should cause no insuperable problems.

1 Toule, G, and Murphy, O, fournal of Hygiene (Cambridge), 1978, 81, 161.

\section{Who cares for the mentally handicapped?}

Established policies for the care of both the mentally ill and the mentally handicapped have been challenged and almost reversed in recent years. In the nineteenth century the asylum was a place of refuge for idiots; and Colonel W W Ireland, among others, made a plea for more adequate medical care in such places. The notion that institutions protected such people from being exploited by the public persisted until the beginning of the National Health Service-the question "Whether ever in moral danger?" being printed in local authority case notes alongside "Whether convicted or been in the hands of the police ?" There was also a strong lobby in favour of stopping the "propagation of the unfit" by locking them up.

Not surprisingly, with this legacy of different and sometimes contradictory goals, hospitals for the mentally retarded are not ideally equipped as a base for rehabilitation for life in the community or even as a substitute home for the inmates. These hospitals became an integral part of the Health Service when it was founded; but, as Professor P Mittler and his colleagues of the National Development Group for the Mentally Handicapped say in their report to the Secretary of State for Social Services, these institutions often find it hardw to get expert help for the many complications to which the 3 mentally retarded are prone. ${ }^{1}$ The report sets an ironic goal-@ to ensure at least as good a quality of specialist help for those $\leftarrow$ who happen to be in hospital as for those who live in the community.

In his introduction to the report Mr David Ennals admits음 that mental handicap hospitals have long been one of the most $\frac{}{5}$ neglected and deprived areas of the NHS: though manyळ improvements have been made recently, any visitor cannot faile to be impressed, he points out, by the contrast between the $\vec{O}$ life lived by many of the residents and that which most of us enjoy. The Secretary of State commends improvements that $\vec{\sigma}$ can be made within existing resources but makes no promises about additional financial help. But, as this report shows, more funds are essential from both the NHS and local ${ }_{0}^{N}$ authorities if we are to achieve any real improvement.

Some 50000 citizens of Britain are living in hospitals for. the mentally handicapped, and 20000 have lived in hospitals $\vec{\infty}$ for 20 years or more. The report repeats that many thousands $\odot$ do not need to be in hospital at all and wants the Government to do much more to provide the resources required by the $\vec{\infty}$ policy of community care.

Meanwhile we are left with hospitals as they are and this report spells out the shortcomings. One of the cardinal 3 problems at present is lowered morale and uncertainty about $\stackrel{\Phi}{-}$ the future. Money for more nurses is hard to come by; $\vec{\theta}$ reducing beds improves the ratio, but even when there is $\infty$ money for staff those of the right calibre may not be forthcoming. And the discontent of nurses extends to other professions.

The report again commends a district attachment for the psychiatrist concerned with the mentally handicapped; and it $\stackrel{\odot}{\stackrel{1}{\varrho}}$ again emphasises that we should avoid consigning mentally $\overrightarrow{\overrightarrow{0}}$ handicapped children to hospital, and instead put them under 3 the care of paediatricians and community physicians. Doctors and other specialists are, however, reluctant to opt for this work, while deplorably few psychiatrists in training are prepared to devote themselves to the care of the mentally handicapped.

We need more work like that of pioneers such as Lionel Penrose to raise the academic status of the subject; the $\frac{\rho}{3}$ Medical Research Council and the universities should give a clearer lead. Uncertainty should be ended, and if these hospitals are to stay for 20 to 40 years or more this must be $\widetilde{N}$ said boldly. Joint funding by the NHS and local authorities $\frac{7}{0}$ may be a partial answer. At all events, professional staff must be guaranteed a future within an integrated service for the $\mathcal{N}$ mentally handicapped.

1 National Development Group for the Mentally Handicapped, Helping 0 Mentally Handicapped People in Hospital: a report to the Secretary of $\overline{\mathscr{C}}$ State for Social Services. London, Department of Health and Social $\stackrel{\mathscr{P}}{+}$ Security, 1978. 